\title{
PERAN BUDAYA ORGANISASI PENDIDIKAN ISLAM \\ DALAM MENGHADAPI TANTANGAN PEMBANGUNAN MASYARAKAT, NEGARA DAN BANGSA \\ Oleh: Unang Wahidin*
}

\begin{abstract}
Abstrak
Untuk menghadapi tantangan di masa datang, organisasi pendidikan Islam diharapkan dapat menghasilkan sumber daya manusia yang bermutu, yang tidak saja tinggi kemampuan ilmu pengetahuan dan teknologinya (iptek), tetapi juga harus dilandasi iman dan

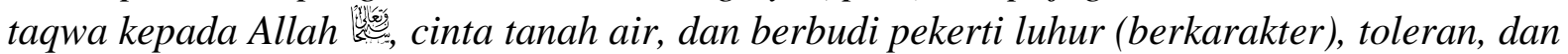
bahkan dari pendidikan Islam yang dapat melahirkan manusia yang mampu menghargai keanekaragaman budaya antar bangsa di dunia (cross-cultural education). Untuk menghasilkan sumber daya manusia yang bermutu tersebut dituntut adanya budaya (kultur akademis) dari organisasi pendidikan Islam sehingga mampu mengembangkan dirinya menjadi organisasi yang sehat dengan ciri-ciri: organisasi yang efektif mengantarkan kepada tujuan; struktur organisasi yang kokoh; orang-orang yang ada pada struktur memiliki kompetensi akademik, pemahaman yang benar, pengalaman dan keterampilan, keperibadian dan sikap yang benar yang menyebabkan organisasi maju; pemimpin memiliki kompetensi akademik, pemahaman, pengalaman, keterampilan, serta kepemimpinan yang maтри memimpin, mengelola dan mensinergikan semua sumberdaya untuk kemajuan organisasi.
\end{abstract}

Key Word: Budaya Organisasi, Pendidikan Islam, Menghadapi Tantangan.

\section{A. PENDAHULUAN}

Dewasa ini sistem pendidikan nasional menghadapi tantangan yang cukup besar dan mendasar, terutama dalam konteks pembangunan masyarakat, negara dan bangsa. Tantangan itu dirasakan sehubungan dengan keadaan dan permasalahan di berbagai bidang kehidupan yang secara langsung memiliki kaitan dengan sistem pendidikan nasional. Tantangan tersebut berasal dari dua faktor yang saling berpengaruh, baik dari faktor luar (ekstern) maupun dari faktor yang berasal dari dalam (intern). Berkaitan dengan hal tersebut, pendidikan Islam sebagai salah satu sub sistem dari sistem pendidikan nasional dituntut untuk selalu melakukan perubahan dan pengembangan agar mampu merespon dan mengatasi berbagai tantangan tersebut.

Tantangan-tantangan yang menuntut organisasi pendidikan Islam harus berubah dan berkembang setidaknya dapat diidentifikasi sebagai berikut:
1. Menuju keunggulan bidang pendidikan Islam;

2. Pembentukan karakter bangsa;

3. Penguasaan ilmu dan teknologi;

4. Memperkokoh integrasi bangsa;

5. Menuju sistem pembelajaran dan penilaian yang efektif.

\section{B. Pembahasan}

1. Tantangan Terhadap Organisasi Pendidikan Islam

a. Menuju Keunggulan Bidang Pendidikan Islam

Term pendidikan dalam konteks Islam umumnya mengacu pada beberapa term, pertama al-tarbiyah, yang memiliki arti dasar tumbuh, berkembang, memelihara, merawat, mengatur dan menjaga kelestarian atau eksistensinya ${ }^{1}$.

Kedua, al-ta'lim sebagai proses transfer berbagai ilmu pada jiwa individu

* Dosen Tetap Prodi PAI STAI Al-Hidayah Bogor

Al-Rasyidin dan Syamsul Rizal, Filsafat Pendidikan Islam, Jakarta, Ciputat Press, 2005, hlm: 25. 
tanpa adanya batasan dan ketentuan tertentu.

Ketiga, menurut Al-Attas yang paling tepat untuk menunjukan pendidikan Islam adalah $a l-t a$ 'dib yang artinya mendidik ${ }^{2}$.

Adapun pengertian pendidikan Islam secara terminologi, para ahli pendidikan Islam telah mencoba memformulasikannya sebagai berikut:

1) Al-Syaibani; menjelaskan bahwa pendidikan Islam adalah proses mengubah tingkah laku individu peserta didik pada kehidupan pribadi, masyarakat dan alam sekitarnya ${ }^{3}$.

2) Ahmad Tafsir, mendefinisikan pendidikan Islam sebagai bimbingan yang diberikan oleh seseorang agar ia berkembang secara maksimal sesuai dengan ajaran Islam ${ }^{4}$.

3) Endang Saifuddin Anshori, mengemukakan bahwa pendidikan Islam dalam arti luas merupakan proses bimbingan oleh subjek didik terhadap perkembangan jiwa dan raga ke arah terciptanya pribadi Islami ${ }^{5}$.

Berdasarkan beberapa definisi di atas maka dapat disimpulkan bahwa pendidikan Islam adalah segenap kegiatan yang dilakukan seseorang atau lembaga untuk menanamkan nilai-nilai Islam ke dalam diri seseorang atau kelompok. Hal ini sejalan dengan pernyataan Haidar Putra Daulay yang menyatakan bahwa hakikat pendidikan Islam adalah pendidikan yang bertujuan untuk membentuk peribadi muslim seutuhnya, mengembangkan seluruh potensi manusia baik yang berbentuk jasmani maupun rohani ${ }^{6}$. Dengan

2 Muhammad Naquib al-Attas, Konsep Pendidikan dalam Islam, Terj. Haidar Bagir, Bandung, Mizan, 1999, hlm:60.

3 Omar Muhammad Al-Toumy Al-Syaibany, Falsafah Pendidikan Islam, Jakarta, Bulan Bintang, 1979, hlm:399.

4 Ahmad Tafsir, Ilmu Pendidikan dalam Perspektif Islam, Bandung, Remaja Rosda Karya, 1992.

5 Endang Saifuddin Anshari, Wawasan Islam, Jakarta, CV. Rajawali, 1986, hlm:184.

6 Haidar Putra Daulay, Pendidikan Islam, Kencana Premada Media Group, hlm:4. kata lain, pendidikan Islam merupakan proses pembentukan manusia ke arah yang dicita-citakan Islam. Senada dengan ungkapan di atas, secara eksplisit juga disampaikan bahwa salah satu fungsi utama pendidikan Islam adalah menanamkan ajaran Islam ke dalam kehidupan masyarakat atau mengislamkan masyarakat ${ }^{7}$.

Memasuki abad ke-21, pergaulan antar bangsa telah berkembang menjadi dunia tanpa batas (borderless), baik dalam bentuk batas geografis, politis, ekonomi, maupun batas sosial budaya. Tidak ada satu negara pun di belahan dunia ini yang tanpa saling berhubungan secara timbal balik antara satu dengan yang lain (reciprocal relationship) untuk memiliki posisi tawar dalam konteks hubungan dan kerja sama antar negara. Diperlukan keunggulan komparatif dan kompetitif sumber daya manusia negara satu dengan negara lain yang akan saling memerlukan secara timbal balik, karena adanya perbedaan kondisi dan potensi sumber daya alam dan sumber daya manusia yang dimilikinya.

Untuk menjawab tantangan tersebut, pendidikan Islam harus bermutu, baik dari segi masukan, proses maupun hasil pendidikannya. Dari organisasi pendidikan Islam yang bermutu diharapkan dapat menghasilkan keunggulan sumber daya manusia, tidak hanya dari aspek akademik, tetapi juga dalam hal seni, olah raga, disiplin dan keterampilan untuk dapat hidup dalam masyarakat yang sedang mengalami perubahan yang cepat. Dalam konteks tujuan pendidikan Islam, manusia yang unggul adalah manusia yang cerdas dan berwatak baik dalam bidang kecerdasan intelektual, sosio-emosional maupun spiritual. Manusia seperti inilah yang diharapkan akan dapat berguna dalam dunia yang sedang berubah, dan mampu mencapai keunggulan dalam era persaingan global.

Abuddin Nata, Pendidikan Islam di Indonesia, Tantangan dan Peluang, Ciputat, 2004, hlm: 1. 
Kecakapan dasar yang dapat dipersiapkan oleh organisasi pendidikan Islam sehingga dapat digunakan untuk masa yang akan datang sebagaimana dalam konsep minimum essential learning needs ${ }^{8}$ yang terdiri atas: a. Sikap positif terhadap kerja sama dengan dan membantu keluarga, teman, pekerja, masyarakat dan pembangunan nasional serta nilai-nilai etis; b. Keaksaraan dan berhitung fungsional, yakni dapat membaca dan mengerti isinya, menulis surat penting, menanyakan informasi dan menghitung hal umum; c. Pandangan ilmiah dan pemahaman sederhana tentang hukum alam, seperti kesehatan, sanitasi, gizi, dan lingkungan; d. Pengetahuan dan keterampilan fungsional untuk mengasuh keluarga dan rumah tangga; e. Pengetahuan dan keterampilan fungsional untuk mencari nafkah; f. Serta pengetahuan dan keterampilan fungsional untuk kewarganegaraan seperti tentang sejarah, ideologi, struktur pemerintah, pajak, pendapatan, dan layanan sosial yang tersedia.

Sedangkan Shane ${ }^{9}$ mengatakan, ada dua keterampilan masa depan yang penting untuk diajarkan, yaitu: a. coping skills, yaitu keterampilan dalam mengatasi perubahan cepat di segala bidang; dan b. planning techniques skills, yaitu keterampilan tentang rencana-rencana masa depan, mengatur waktu, energi, dan uang, sedemikian rupa untuk menjadikan keadaan lebih baik. Kedua keterampilan ini harus dilatihkan dengan sebaik-baiknya kepada peserta didik yang terkadang sulit diperoleh karena keduanya tidak dapat diperoleh melalui kuliah atau ceramah.

8 Comb, 1973, hlm.15 dalam Saleh Marzuki, Pendidikan Nonformal, Dimensi dalam Keaksaraan Fungsional, Pelatihan, dan Andragogi, Bandung, Remaja Rosdakarya, 2010, hlm.242.

9 Shane, 1974, hlm.191 dalam Saleh Marzuki, Pendidikan Nonformal, Dimensi dalam Keaksaraan Fungsional, Pelatihan, dan Andragogi, Bandung, Remaja Rosdakarya, 2010, hlm.242.
Setelah dilakukan pengkajian terbatas tentang tuntutan globalisasi, tuntutan reformasi, suasana belajar masa depan dan keterampilan masa depan, maka teridentifikasi sejumlah kebutuhan belajar minimum masa depan, yakni: ${ }^{10} 1$ ) kemampuan membaca, menulis, dan berhitung fungsional; 2) kemampuan bekerja sama; 3) kemampuan berpikir ilmiah; 4) kemampuan mengasuh keluarga dan berumah tangga; 5) kemampuan mencari nafkah; 6) kemampuan memahami kewarganegaraan; 7) sikap dan motivasi untuk gemar belajar; 8) kemampuan memperoleh dan menguasai informasi; 9) kemampuan berkomunikasi; 10) kemampuan berorganisasi; 11) kemampuan beradaptasi dan mengatasi perubahanperubahan yang cepat; 12) kemampuan teknik perencanaan masa depan, mengatur waktu, tenaga, dan uang; 13) kemampuan bersaing; 14) sikap keterbukaan; 15) sikap peduli kepada sesama dan menghargai martabat manusia; dan 16) suka menghargai perbedaan dan keragaman.

Tentu sebagai organisasi pendidikan Islam dalam mempersiapkan kecakapan dan keterampilan dasar peserta didik untuk masa depan harus selalu didasari oleh penanaman keimanan dan ketakwaan terhadap Allah telah bersemayam dalam diri seseorang dan menjadi karekter sebuah masyarakat, ia akan membuahkan perbuatan baik. Tauhid merupakan pintu kebaikan dan pertolongan Allah Kita diingatkan oleh Allah dengan firman-Nya dalam Qur'an AlA'raaf ayat 96 , yang berbunyi:

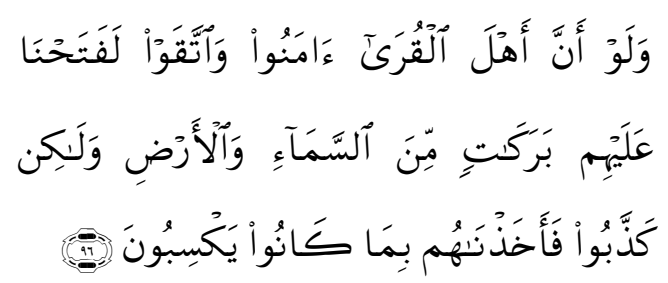

10 Saleh Marzuki, Pendidikan Nonformal, Dimensi dalam Keaksaraan Fungsional, Pelatihan, dan Andragogi, Bandung, Remaja Rosdakarya, 2010, hlm. 243 . 
"Jikalau Sekiranya penduduk negerinegeri beriman dan bertakwa, pastilah Kami akan melimpahkan kepada mereka berkah dari langit dan bumi, tetapi mereka mendustakan (ayat-ayat Kami) itu, Maka Kami siksa mereka disebabkan perbuatannya."

Tauhid akan mengangkat derajat orang-orang yang beriman menjadi luhur, padahal sebelumnya mereka terpuruk. Pintu-pintu keagungan di dunia terbuka melalui tauhid. Ketika tauhid tertanam dalam jiwa para peserta didik, yang akan tersiar dari mereka adalah semangat juang untuk hidup lebih baik. Sebaliknya, ketika tauhid redup dari relung jiwa peserta didik, redup pula semangat juang dalam diri mereka. Itulah pentingnya tauhid dibangun supaya menjadi karakter peserta didik kita untuk kehidupan mereka di masa yang akan datang.

\section{b. Pembentukan Karakter Bangsa}

Pendidikan Islam diharapkan dapat menghasilkan manusia yang tidak saja tinggi kemampuan ilmu pengetahuan dan teknologinya (iptek), tetapi juga harus dilandasi iman dan taqwa yang kuat kepada Allah cinta tanah air, dan berbudi pekerti luhur (berkarakter), toleran, dan bahkan dari pendidikan Islam yang dapat melahirkan manusia yang mampu menghargai keanekaragaman budaya antar bangsa di dunia (cross-cultural education).

Karakter adalah watak, tabiat, akhlak, atau kepribadian seseorang yang terbentuk dari hasil internalisasi berbagai kebajikan (virtues) yang diyakini dan digunakan sebagai landasan untuk cara pandang, berpikir, bersikap, dan bertindak. Kebajikan terdiri atas sejumlah nilai, moral, dan norma, seperti: jujur, berani bertindak, dapat dipercaya, dan hormat kepada orang lain. $^{11}$

11 Kementerian Pendidikan Nasional, Badan Penelitian Dan Pengembangan, Pusat Kurikulum, Pengembangan Pendidikan Budaya
Sedangkan pengertian karakter dalam Kamus Lengkap Bahasa Indonesia didefinisikan sebagai tabiat, sifat-sifat kejiwaan, akhlak atau budi pekerti yang membedakan seseorang dengan yang lain. Secara terminologi, karakter adalah sikap pribadi yang stabil dan hasil proses konsolidasi secara progresif dan dinamis, integrasi pernyataan dan tindakan. ${ }^{12}$

Karakter atau identitas diri berpangkal pada "Culture matters". Untuk membangun karakter diperlukan sikap dan orientasi nilai-nilai yang kondusif, diantaranya adalah: Sikap, orientasi dan praksis saling percaya (trust bukan prasangka), disiplin kerja keras (jangan hanya menyalahkan pihak lain), juga intropeksi, hemat cermat, mengutamakan pendidikan, berlakunya rule of law, menimba secara kritis konstruktif sikap hidup bersama, dan identitas kita bersama sebagai suata bangsa. ${ }^{13}$

Interaksi seseorang dengan orang lain menumbuhkan karakter bangsa. Oleh karena itu, pengembangan karakter hanya dapat dilakukan melalui pengembangan karakter individu seseorang. Akan tetapi, karena peserta didik hidup dalam ligkungan keluarga, sekolah dan masyarakat tertentu, maka pengembangan karakter peserta didik hanya dapat dilakukan dalam lingkungan keluarga, sekolah dan lingkungan masyarakat bersangkutan. Artinya, pengembangan karakter hanya dapat dilakukan dalam suatu proses pendidikan yang tidak melepaskan peserta didik dari lingkungan keluarga, sekolah, dan budaya masyarakat.

Dalam teori pendidikan Islam, karakter bukan barang beku yang tidak mengalami pergeseran dan perubahan. Dengan berbagai upaya yang serius, karakter dapat diubah. Tobat (taubah) merupakan konsep paling jelas yang

Dan Karakter Bangsa, Pedoman Sekolah, Jakarta, 2010, hlm.3.

12 Endin Mujahidin, Seminar Pendidikan Karakter Dalam Perspektif Pendidikan Islam, Bogor, STAI Al Hidayah Bogor, 11 Maret 2012.

13 Bung Hata, dalam Yakob Oetama, 2006. 
menerjemahkan bahwa karakter bisa diubah dan dididik. Bukan hal mustahil ada orang yang menjadi baik (saleh), padahal sebelumnya dia sebagai manusia yang jahat. Selanjutnya A. Helmy Faishal Zaini, memaparkan pilar-pilar pendidikan karakter islami sebagai berikut: a. meyakini Tuhan; b. kesabaran; c. kebijaksanaan; d. murah hati; e. silaturrahmi; f. kejujuran; g. kasih sayang; h. membahagiakan orang lain; i.kerukunan antar sesama; j. simpatik pada kelompok tertindas; $\mathrm{k}$. tepat janji dan menjaga amanah; 1. rendah hati; m. mandiri dan kreatif; n. sopan dan santun; o. menghormati orang yang lebih tua dan menyayangi yang lebih muda; p. jiwa persaudaraan; q. syukur nikmat. ${ }^{14}$

Atas dasar pemikiran tersebut, pengembangan pendidikan karakter peserta didik sangat strategis bagi keberlangsungan dan keunggulan bangsa di masa mendatang. Pengembangan itu harus dilakukan melalui perencanaan yang baik, pendekatan yang sesuai, dan metode belajar serta pembelajaran yang efektif. Sesuai dengan sifat suatu nilai, pendidikan karakter peserta didik adalah usaha bersama antara keluarga, sekolah dan masyarakat.

\section{c. Penguasaan Ilmu dan Teknologi}

Salah satu pendekatan pendidikan yang dianut banyak negara adalah pendidikan akademis, yang lebih mementingkan penguasaan iptek. Untuk memenuhi kebutuhan tersebut, maka pendidikan Islam harus dilengkapi dengan sarana dan prasarana yang memadai, guru yang kompeten, proses pembelajaran yang tidak hanya mementingkan penguasaan teori dan konsepsi, melainkan juga harus mementingkan penguasaan penerapan teori itu melalui kegiatan praktik di lapangan dan laboratorium.

\section{d. Perlu Memperkokoh Integrasi Bangsa}

Mengacu pada pendidikan kita dan rumusan UNESCO (1972) yaitu learning to

14 A. Helmy Faishal Zaini, Pilar-Pilar Pendidikan Karakter Islami, Bandung, Gunung Djati Press dan Sahifa, 2013. know (belajar untuk mengetahui sesuatu), learning to do (belajar untuk melakukan sesuatu), learning to be (belajar untuk kepentingan dan kemajuan kehidupannya), dan learning to live together (belajar untuk hidup bersama), maka diperlukan sumber daya manusia yang memiliki wawasan, keahlian dan keterampilan agar dapat menghasilkan karya yang bermutu dan dapat bersaing, serta watak dan semangat nasionalisme. Pendidikan Islam diharapkan mampu menghasilkan sumber daya manusia dengan kemampuan tersebut.

\section{e. Menuju Sistem Pembelajaran dan Penilaian yang Efektif}

Perubahan sistem pembelajaran dan penilaian hasil pembelajaran harus menjadi bagian yang integral berupa perubahan dari dalam, yang dilakukan oleh, dari dan untuk semua stakeholder pendidikan Islam. Dengan demikian, perubahan itu tidak dipaksakan dari pihak luar, melainkan dirasakan sebagai kebutuhan dari dalam.

Selain berbagai tantangan tersebut di atas, pendidikan Islam di Indonesia juga masih mengalami permasalahan mandasar yang telah ada sejak lama dan belum juga terpecahkan yaitu: pemerataan pendidikan Islam, mutu dan relevansi pendidikan Islam, dan inefisiensi manajemen pendidikan Islam. Tantangan dan permasalahan yang dihadapi oleh pendidikan Islam tersebut menuntut dilakukannya perubahan dalam organisasi pendidikan Islam secara terencana, sistematik dan terus menerus.

\section{Pengembangan Budaya Organisasi Pendidikan Islam}

\section{a. Latar Belakang Berdirinya Organisasi Pendidikan Islam}

Secara harfiah, kata organisasi berasal dari Bahasa Yunani "organon" yang berarti alat atau instrumen ${ }^{15}$. Arti kata

15 Gareth Morgan, The Image of Organization, London, SAGE Publication, hlm:15, dalam Achmad Sibirin, Budaya Organisasi, Pengertian, Makna, dan aplikasinya dalam 
ini menyiratkan bahwa organisasi adalah alat bantu manusia. Jadi, ketika seseorang mendirikan organisasi, tujuan akhirnya bukan organisasi itu sendiri melainkan ia dan semua orang yang terlibat di dalamnya dapat mencapai tujuan lain lebih mudah dan lebih efektif. Itulah sebabnya organisasi sering didefinisikan sebagai sekelompok manusia (group of people) yang bekerja bersama-sama dalam rangka mencapai tujuan bersama (common goals $)^{16}$. Definisi ini menunjukan adanya dua esensi dasar dari sebuah organisasi yakni sekelompok manusia dan tujuan bersama yang hendak dicapai.

Sedangkan pendidikan adalah salah satu sarana terpenting yang akan menentukan kedudukan sebuah bangsa, karena hakikatnya pendidikan, baik formal, (informal), maupun non formal adalah tempat pengembangan sumber daya manusia, membangun dan mengolah segala potensi yang ada agar menjadi manusiamanusia yang berkualitas. Tidak ada satu bangsa pun yang dapat berkembang dengan menjadi bangsa maju dan besar, kecuali memiliki sistem pendidikan yang baik pula $^{17}$.

Pendidikan dapat dipandang sebagai organisasi, yang memiliki struktur tertentu dan melibatkan sejumlah orang dengan tugas melaksanakan suatu fungsi untuk memenuhi suatu kebutuhan. Berdasarkan perspektif tersebut jelas bahwa penyelenggaraan persekolahan merupakan usaha yang terorganisasi dan memiliki berbagai sumber daya untuk pencapaian

Kehidupan Organisasi, Yogyakarta, UPP STIM YKPN, 2007, hlm:5.

16 John R. Schermerhorn, Jr., 1996, Management, $5^{\text {th }}$ edition, New York: John Wiley and Sons, Inc, hlm:7 dalam Achmad Sibirin, Budaya Organisasi, Pengertian, Makna, dan aplikasinya dalam Kehidupan Organisasi, Yogyakarta, UPP STIM YKPN, 2007, hlm:5.

17 Hilmy Bakar Almascaty, Membangun Kembali Sistem Pendidikan Kaum Muslimin, Jakarta, Universitas Islam Azzahra, 2000, hlm:98. sumber daya dan untuk pencapian tujuantujuan pendidikan ${ }^{18}$.

Dilihat dari tingkat organisasi, maka pendidikan Islam dikelola dalam tingkat organisasi yang berbentuk lembaga pendidikan Islam berupa satuan pendidikan untuk memenuhi kebutuhan masyarakat yang dikelola dengan cara-cara yang demokratis. Hal ini dimaknai sebagai implementasi desentralisasi dalam organisasi pendidikan, sebagai wujud dari tuntutan kehidupan demokrasi. Organisasi pendidikan Islam yang dirancang melalui sistem desentralisasi adalah pendidikan yang berwawasan mutu yang mampu menjawab tantangan global. Pendidikan Islam berada di tangan segenap lapisan masyarakat untuk mewujudkan aspirasi pendidikan. Pendidikan Islam mulai dikembangkan dan dikelola oleh, dari, dan untuk kepentingan masyarakat dengan berbagai dukungan pemerintah.

\section{b. Faktor-Faktor yang Mempengaruhi Perkembangan Organisasi Pendidikan Islam}

Faktor lingkungan eksternal berpengaruh besar terhadap kemajuan atau kegagalan organisasi dalam upayanya mencapai tujuan. Faktor ekonomi, politik, hukum, budaya adalah contoh yang secara signifikan berpengaruh terhadap kinerja individu yang rendah, tingkat absensi yang tinggi, tingkat perputaran karyawan yang tinggi, target tidak tercapai ataupun produktivitas karyawan yang rendah, tidak hanya bisa dianalisis di tingkat individu, atau kelompok atau organisasi saja secara parsial, tetapi mungkin merupakan kombinasi dari dua atau tiga tingkatan analisis tersebut ${ }^{19}$.

Menurut teori sistem sosio-teknik, sekolah adalah organisasi terbuka sehingga ia memiliki konsekuensi tambahan yang

18 Abdul Aziz Wahab, Anatomi Organisasi dan Kepemimpinan Pendidikan, Bandung, Alfabeta, 2008, hlm:227.

19 Sopiah, Perilaku Organisasional, Yogyakarta, ANDI, 2008, hlm:6. 
lebih kompleks dari pada organisasi tertutup. Sekolah sebagai organisasi terbuka dipengaruhi oleh dua kekuatan eksternal yang sangat menentukan struktur internalnya, yaitu:

Pertama, faktor-faktor seperti standar profesi, harapan-harapan yang ditampilkan melalui lembaga-lembaga pelatihan guru, asosiasi, akreditasi, persyaratan memasuki perguruan tinggi dan sebagainya adalah faktor-faktor yang mempresentasikan pengaruh-pengaruh profesional yang ada di dalam sekolah, tetapi datang dari luar organisasi sekolah.

Kedua, faktor-faktor yang mempengaruhi struktur internal yang mencerminkan pengaruh sosio-kultural yang meliputi pula standar-standar kehidupan dan tradisi yang beragam.

Dengan demikian, organisasi pendidikan Islam dalam sudut pandang teori sistem sosio-teknik, merupakan struktur internal sebagai unikum tersendiri dan dalam saat yang bersamaan ia pun merupakan bagian interaksional dari supra sistem yang melingkupinya.

\section{c. Budaya Organisasi Pendidikan Islam}

Edward B. Tylor-orang pertama yang menggunakan istilah budaya dalam karya Antropologi, misalnya mengatakan bahwa budaya adalah hasil karya manusia dalam kedudukannya sebagai anggota masyarakat. Pengertian budaya seperti yang dikemukakan Edward B. Tylor adalah sebagai berikut: ${ }^{20}$ "Culture or civilization is that complex whole which includes knowledges, belief, art, morals, law, custom, and any other capabilities and habits acquired by man as a member of society”. (Kultur atau peradaban adalah kompleksitas menyeluruh yang terdiri dari pengetahuan, keyakinan, seni, moral, hukum, adat kebiasaan dan berbagai

20 E.B. Tylor, The Origin Of Culture, halm:1 dalam Achmad Sobirin, Budaya Organisasi, Pengertian, Makna, dan Aplikasinya dalam Kehidupan Organisasi, Yogyakarta, UPP STIM YKPN, 2007, hlm:52. kapabilitas lainnya serta kebiasaan apa saja yang diperoleh manusia sebagai bagian dari sebuah masyarakat). Atau seperti yang dikemukakan Bronislaw Malinowski ${ }^{21}$ sebagai berikut: Kultur adalah keseluruhan kehidupan manusia yang integral yang terdiri dari berbagai peralatan dan barangbarang konsumen, berbagai peraturan untuk kehidupan masyarakat, ide-ide dan hasil karya manusia, keyakinan dan kebiasaan manusia.

Adapun Andrew Pettigrew ${ }^{22}$ orang pertama yang menggunakan istilah budaya organisasi, memberikan pengertian budaya organisasi sebagai " the system of such publicly and collectively accepted meanings operating for given group at a given time" (budaya adalah sistem makna yang diterima secara terbuka dan kolektif, yang berlaku untuk waktu tertentu bagi sekelompok orang tertentu). Esensi budaya organisasi adalah sistem makna atau jaringan makna. Untuk memperjelas bagaimana sistem makna bisa menjadi esensi budaya organisasi, Andrew Pettigrew memberi pengertian sistem sebagai istilah (terminologi), bentuk, kategori atau citra (image) yang bisa dengan sendirinya menjelaskan situasi diri sekelompok orang kepada orang tersebut. Dalam hal ini sistem makna diharapkan bisa memberi gambaran tentang jati diri (budaya) sebuah organisasi kepada orangorang yang bekerja pada organisasi tersebut dan orang-orang yang berada di luar organisasi melalui proses pemaknaan terhadap semua aspek kehidupan organisasi.

21 Malinowski sebagaimana dikutip William M. Evan hlm: 267, dalam Achmad Sobirin, Budaya Organisasi, Pengertian, Makna, dan aplikasinya dalam Kehidupan Organisasi, Yogyakarta, UPP STIM YKPN, 2007, hlm:52.

22 Andrew Pettigrew, 1979, On Studying Organizational Culture, Administrative Science Quarterly, hlm:570-581 dalam Achmad Sibirin, Budaya Organisasi, Pengertian, Makna, dan aplikasinya dalam Kehidupan Organisasi, Yogyakarta, UPP STIM YKPN, 2007, hlm:129. 
Dalam kehidupan masyarakat seharihari tidak terlepas dari ikatan budaya yang diciptakan. Ikatan budaya tercipta oleh masyarakat bersangkutan, baik dalam keluarga, organisasi, bisnis maupun bangsa. Budaya membedakan masyarakat satu dengan yang lain dalam cara berintekrasi dan bertindak menyelesaikan suatu pekerjaan. Budaya mengikat anggota kelompok masyarakat menjadi satu kesatuan pandangan yang menciptakan keseragaman berperilaku dan bertindak. Seiring dengan bergulirnya waktu, budaya pasti terbentuk dalam organisasi dan dapat pula dirasakan manfaatnya dalam memberi kontribusi bagi efektivitas organisasi secara keseuruhan $^{23}$.

Budaya organisasi dipengaruhi oleh beberapa faktor, yaitu:

a. Pengaruh umum dari luar yang luas, mencakup faktor-faktor yang tidak dapat dikendalikan atau hanya sedikit dapat dikendalikan oleh organisasi.

b. Pengaruh dari nilai-nilai yang ada di masyarakat, keyakinan-keyakinan dan nilai-nilai yang dominan dari masyarakat luas misalnya, kesopansantunan dan kebersihan.

c. Faktor-faktor yang spesifik dari organisasi. Organisasi selalu berinteraksi dengan lingkungannya. Dalam mengatasi baik masalah eksternal maupun internal organisasi akan mendapatkan penyelesaianpenyelesaian yang berhasil. Keberhasilan menyelesaikan berbagai masalah tersebut merupakan dasar bagi tumbuhnya budaya organisasi.

Pemahaman budaya organisasi sesungguhnya tidak lepas dari konsep dasar tentang budaya itu sendiri, yang merupakan salah satu terminologi yang banyak digunakan dalam bidang antropologi. Dewasa ini budaya diartikan sebagai manifestasi kehidupan setiap orang dan

23 Abdul Aziz Wahab, Anatomi Organisasi dan Kepemimpinan Pendidikan, Bandung, Alfabeta, 2008, hlm:229-230. setiap kelompok orang-orang. Kini budaya dipandang sebagai sesuatu yang lebih dinamis, bukan sesuatu yang kaku dan statis. Budaya tidak diartikan sebagai suatu kata benda, kini lebih dimaknai sebagai sebuah kata kerja yang berhubungan dengan kegiatan manusia. Dalam budaya organisasi ditandai adanya sharing atau berbagi nilai dan keyakinan yang sama dengan seluruh anggota organisasi.

Islam memandang budaya organisasi memiliki peran yang sangat penting dalam kehidupan. Namun demikian ajaran Islam yang sempurna dan baik untuk segala zaman dan tempat tidak tampak menarik dan mengundang simpatik karena budaya yang ditunjukan ummatnya sangat jauh dari nilai-nilai Islam itu sendiri.

Dalam dunia pendidikan istilah budaya organisasi dikenal dengan kultur akademis yang intinya berarti mengatur para pendidik agar mereka memahami bagaimana seharusnya bersikap terhadap perofesinya, beradaptasi terhadap rekan kerja dan lingkungan kerjanya serta berlaku reaktif terhadap kebijakan pimpinannya, sehingga terbentuklah sistem nilai, kebiasaan (habit), citra akademis, etos kerja yang terinternalisasikan dalam kehidupannya sehingga mendorong adanya apresiasi dirinya terhadap peningkatan prestasi kerja baik terbentuk oleh lingkungan organisasi itu sendiri maupun dikuatkan secara organisatoris oleh pimpinan akademis yang mengeluarkan kebijakan yang diterima ketika seseorang masuk organisasi tersebut. Luthans $^{24}$ menyebutkan sejumlah karakteristik yang penting dari budaya organisasi yang meliputi:

a. Aturan-aturan perilaku, yaitu bahasa, terminologi dan ritual yang biasa dipergunakan oleh anggota organisasi.

b. Norma, adalah standar perilaku yang meliputi petunjuk bagaimana

\footnotetext{
24 Luthans dalam Muhammad Jamal dkk, Makalah Perilaku dan Budaya Organisasi Pendidikan Islam, Program Pasca Sarjana, Magister Agama Islam UIKA, Bogor, 2010, hlm:9.
} 
melakukan sesuatu, lebih jauh di masyarakat kita kenal adanya norma agama, norma sosial, norma susila, norma adat dan lain-lain.

c. Nilai-nilai dominan, adalah nilai utama yang diharapkan dari organisasi untuk dikerjakan oleh para anggotanya, misalnya tingginya kualitas kerja, rendahnya tingkat absensi, tingginya produktivitas dan efisiensi, serta tingginya disipin kerja.

d. Filosofi, adalah kebijakan yang dipercaya organisasi tentang hal-hal yang disukai para karyawan dan pelanggannya, seperti "kepuasan anda adalah harapan kami", "berdiri di atas dan untuk semua golongan".

e. Peraturan-peraturan, adalah aturan yang tegas dari organisasi. Pegawai baru harus mempelajari peraturan ini agar keberadaannya dapat diterima di dalam organisasi.

f. Iklim organisasi, adalah keseluruhan "perasaan" yang meliputi hal-hal fisik, bagaimana para anggota berinteraksi dan bagaimana para anggota organisasi mengendalikan diri dalam berhubungan dengan pelanggan atau pihak luar organisasi.

\section{d. Organisasi Pendidikan Islam yang Sehat}

Organisasi pendidikan Islam yang sehat adalah organisasi yang mampu mengembangkan sayapnya disertai kemajuan pelaku organisasi itu sendiri dan mampu memberikan kontribusi yang memuaskan sesuai harapan baik bagi pengurus, anggotanya maupun masyarakat luas. Organisasi pendidikan Islam yang sehat adalah suatu badan atau perkumpulan yang bergerak dalam penyebaran ilmu yang terhindar dari berbagai kekeliruan dan sesuatu yang tidak jelas/meragukan baik bagi pelaku organisasi itu sendiri maupun perangkat organisasinya.
Beberapa ciri organisasi (pendidikan Islam) yang sehat ${ }^{25}$, yaitu:

a. Organisasi yang efektif mengantarkan kepada tujuan;

b. Struktur organisasi yang kokoh;

c. Orang-orang yang ada pada struktur memiliki kompetensi akademik, pemahaman yang benar, pengalaman dan keterampilan, keperibadian dan sikap yang benar yang menyebabkan organisasi maju;

d. Pemimpin memiliki kompetensi akademik, pemahaman, pengalaman, keterampilan, serta kepemimpinan yang mampu memimpin, mengelola dan mensinergikan semua sumberdaya untuk kemajuan organisasi.

Organisasi pendidikan Islam yang sehat bisa dilihat dari berbagai indikator yang melingkupinya, diantaranya adalah:

\section{a. Visi Organisasi}

Visi adalah wawasan yang menjadi sumber arahan bagi organisasi pendidikan Islam dan digunakan untuk membantu perumusan visi organisasi. Dengan kata lain, visi adalah pandangan jauh ke depan kemana organisasi akan dibawa. Visi adalah gambaran masa depan yang diinginkan oleh organisasi pendidikan Islam, agar organisasi pendidikan Islam dapat menjamin kelangsungan hidup dan perkembangannya $^{26}$.

Gambaran tersebut tentunya harus didasarkan pada landasan yuridis, yaitu undang-undang pendidikan dan sejumlah peraturan pemerintahnya, khususnya peraturan pendidikan nasional sesuai jenjang dan jenis sekolahnya dan juga sesuai dengan profil sekolah yang bersangkutan. Dengan kata lain, visi organisasi pendidikan Islam harus tetap dalam koridor kebijakan pendidikan nasional.

\footnotetext{
25 Abuddin Nata, Perkuliahan Program Pasca Sarjana, Konsentrasi Manajemen Pendidikan Islam Universitas Ibn Khaldun, 3 Desember 2009.

26 AB. Susanto, Visi dan Misi, hlm:15-16
} 
Visi juga dapat dilihat sebagai pandangan ke depan dengan memperhatikan hal-hal berikut ${ }^{27}$ :

1) Berorientasi ke masa depan yang lebih baik, bukan status quo;

2) Antisipasi tentang kecendrungan perkembangan sejarah, budaya dan nilai-nilai yang dianut organisasi;

3) Keunikan (kekhasan) dan kompetensi yang ditonjolkan;

4) Standar keunggulan, mewujudkan cita-cita yang tinggi dan ambisi yang kuat;

5) Rangsangan inspirasi, antusiasme, dan komitmen;

6) Ke jalan atau sebagai arah untuk mencapai tujuan.

Sebuah visi harus menguraikan secara jelas apa yang ingin dicapai, cita-cita tersebut terukur, secara rasional dapat dicapai dan menetapkan waktu yang diperlukan untuk mencapai cita-cita tersebut. Sebuah visi selanjutnya harus dijabarkan ke dalam misi, tujuan jangka panjang dan tujuan jangka pendek yang merupakan aktivitas pelaksanaan visi dengan jangka waktu yang lebih jelas dan diharapkan terukur sehingga evaluasi mudah dilakukan.

\section{b. Misi Organisasi}

Misi adalah tindakan untuk mewujudkan/merealisasikan visi tersebut. Karena visi harus mengakomodasi semua kelompok kepentingan yang terkait dengan lembaga pendidikan Islam, maka misi dapat juga diartikan sebagai tindakan untuk memenuhi kepentingan masing-masing kelompok yang terkait dengan lembaga pendidikan Islam.

Misi adalah sesuatu yang harus dilakukan oleh organisasi agar tujuan organisasi dapat terlaksana dan berhasil dengan baik. Dengan pernyataan misi tersebut, diharapkan seluruh pegawai dan pihak yang berkepentingan dapat mengenal organisasi dan mengetahui peran dan

27 http://www.qaa.ac.uk program-programnya serta hasil yang akan diperoleh di masa mendatang ${ }^{28}$. Dengan kata lain, misi adalah bentuk layanan untuk memenuhi tuntutan yang dituangkan dalam visi dengan berbagai indikatornya ${ }^{29}$.

\section{c. Tujuan Organisasi}

Tujuan merupakan "apa" yang akan dicapai/dihasilkan oleh organisasi pendidikan Islam yang bersangkutan dan "kapan". Dengan jangka waktu yang panjang, maka tujuan dikaitkan dengan jangka. Dengan demikian tujuan pada dasarnya merupakan tahapan wujud organisasi pendidikan Islam menuju visi yang telah dicanangkan.

Tujuan yang merupakan penjabaran atau implementasi dari pernyataan misi, adalah hasil ukur yang akan dicapai pada jangka waktu tertentu. Dalam hal ini penetapan jangka waktu pencapaian tujuan biasanya adalah selama 5 tahun. Oleh karena itu penetapan tujuan harus dapat menggambarkan isu-isu strategis yang ingin dicapai oleh semua unit-unit kerja dalam suatu organisasi, sehingga dalam pelaksanaannya akan terjadi iklim yang kondusif serta mendorong terjadinya sinergisme.

\section{DAFTAR PUSTAKA}

\section{Buku:}

Al-Attas, Muhammad Naquib, (1979), Konsep Pendidikan dalam Islam, Terj. Haidar Bagir, Bandung.

Almascaty, Hilmy Bakar, (2000), Membangun Kembali Sistem Pendidikan Kaum Muslimin,. Universitas Islam Azzahra.

Al-Rasyidin, Syamsul Rizal, (2005), Filsafat Pendidikan Islam, Jakarta, Ciputat Press.

Al-Syaibany, Omar Muhammad AlToumy,(2008), Falsafah Pendidikan Islam, Jakarta, Bulan Bintang.

\footnotetext{
${ }^{28}$ Sudarmawan Danim, Manajemen Sekolah, 2007.

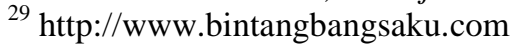


Anshari, Endang Saifuddin, (1986), Wawasan Islam, Jakarta, CV. Rajawali.

Comb, (1973) dalam Saleh Marzuki, (2010), Pendidikan Nonformal, Dimensi dalam Keaksaraan Fungsional, Pelatihan, dan Andragogi, Bandung, Remaja Rosdakarya.

Danim, Sudarmawan, (2007), Manajemen Sekolah.

Daulay, Haidar Putra, Pendidikan Islam, Kencana Premada Media Group.

E.B. Tylor, The Origin Of Culture dalam Achmad Sobirin, (2007), Budaya Organisasi, Pengertian, Makna, dan aplikasinya dalam Kehidupan Organisasi, Yogyakarta, UPP STIM YKPN.

John R. Schermerhorn, Jr., (1996), Management, $5^{\text {th }}$ edition, New York: John Wiley and Sons, Inc.

Kementerian Pendidikan Nasional, Badan Penelitian Dan Pengembangan, Pusat Kurikulum, (2010), Pengembangan Pendidikan Budaya Dan Karakter Bangsa, Pedoman Sekolah, Jakarta.

Luthans dalam Muhammad Jamal dkk, (2010), Makalah Perilaku dan Budaya Organisasi Pendidikan Islam, Program Pasca Sarjana, Magister Agama Islam UIK, Bogor.

Malinowski sebagaimana dikutip William M. Evan dalam Achmad Sobirin, (2007), Budaya Organisasi, Pengertian, Makna, dan aplikasinya dalam Kehidupan Organisasi, Yogyakarta, UPP STIM YKPN.

Marzuki, Saleh, (2010), Pendidikan Nonformal, Dimensi dalam Keaksaraan Fungsional, Pelatihan, dan Andragogi, Bandung, Remaja Rosdakarya.

Morgan, Gareth, The Image of Organization, London, SAGE Publication dalam Achmad Sobirin, (2007), Budaya Organisasi, Pengertian, Makna, dan aplikasinya dalam Kehidupan Organisasi, Yogyakarta, UPP STIM YKPN.

Mujahidin, Endin, Seminar Pendidikan

Karakter Dalam Perspektif

Pendidikan Islam, Bogor, STAI Al

Hidayah Bogor, 11 Maret 2012.

Nata, Abuddin, (2004), Pendidikan Islam di Indonesia, Tantangan dan Peluang, Ciputat.

Pettigrew, Andrew, 1979, On Studying Organizational Culture, Administrative Science Quarterly dalam Achmad Sibirin, (2007), Budaya Organisasi, Pengertian, Makna, dan aplikasinya dalam Kehidupan Organisasi, Yogyakarta, UPP STIM YKPN.

Shane, (1974) dalam Saleh Marzuki, (2010), Pendidikan Nonformal, Dimensi dalam Keaksaraan Fungsional, Pelatihan, dan Andragogi, Bandung, Remaja Rosdakarya.

Sobirin, Achmad, Budaya Organisasi, Pengertian, Makna, dan aplikasinya dalam Kehidupan Organisasi, dalam Achmad Sibirin, (2007), Budaya Organisasi, Pengertian, Makna, dan aplikasinya dalam Kehidupan Organisasi, Yogyakarta, UPP STIM YKPN.

Sopiah, (2008), Perilaku Organisasional, Yogyakarta, ANDI.

Tafsir, Ahmad, (1992), Ilmu Pendidikan dalam Perspektif Islam, Bandung, Remaja Rosda Karya.

Wahab, Abdul Aziz, (2008), Anatomi Organisasi dan Kepemimpinan Pendidikan, Bandung, Alfabeta.

Zaini, A. Helmy Faishal, (2013), PilarPilar Pendidikan Karakter Islami, Bandung, Gunung Djati Press dan Sahifa.

\section{Internet:}

http://www.qaa.ac.uk

http://www.bintangbangsaku.com 